\title{
UJI DAYA HAMBAT EKSTRAK BAWANG DAYAK (Eleutherine palmifolia (L.) Merr.) TERHADAP BAKTERI Salmonella paratyphi
}

\author{
Nor Aini Aida ${ }^{1 *}$, Febri Nur Ngazizah ${ }^{1}$, Miftachul Sobirin ${ }^{1}$, Riky ${ }^{1}$ \\ 1D-III Analis Kesehatan, STikes Borneo cendekia Medika, Kalimantan Tengah, Indonesia \\ e-Mail : norainiaidaaa@gmail.com
}

\begin{abstract}
Dayak onions (Eleutherine palmifolia (L.) Merr.) Is one of the natural ingredients which is often used for medicine in Kalimantan. E. palmifolia used for treatment because it contains secondary metabolite compounds that have potential as antibacterial. Such as phenolic compounds, flavonoids, alkaloids, saponins, tannins and glycosides which are included in polar compounds. This study aims to determine the effect of ethanol extract $70 \% \mathrm{E}$. palmifolia against bacteria Salmonella paratyphi with the extraction method maceration. S. paratyphi is a bacterial pathogen against humans whose habitat is in the digestive tract. This research was conducted to test the extract's antibacterial activity with gradient concentration of $20 \mathrm{mg}$ / $\mathrm{mL}, 30 \mathrm{mg} / \mathrm{mL}, 40 \mathrm{mg} / \mathrm{mL}, 50 \mathrm{mg} / \mathrm{mL}$, and $60 \mathrm{mg} / \mathrm{mL}$ and chloramphenicol as a positive control and sterile aquadest as a negative control. The antibacterial test method used is diffusion method with 5 repetitions. Our results showed that $E$. palmifolia extract could inhibit S. paratyphi growth as evidenced by the presence of an inhibition zone that is formed around paper disk on media with concentration $20 \mathrm{mg} / \mathrm{mL}, 30 \mathrm{mg} / \mathrm{mL}, 40 \mathrm{mg} / \mathrm{mL}, 50 \mathrm{mg} / \mathrm{mL}$, and $60 \mathrm{mg} / \mathrm{mL}$. Where the average diameter of the inhibition zone was $6.6 \mathrm{~mm}, 7.4 \mathrm{~mm}, 8.8 \mathrm{~mm}$, $9.9 \mathrm{~mm}$, respectively fall into the category of ineffective inhibition and $11 \mathrm{~mm}$ is in the weak category. Based on the research that has been done, it was found that there was an effect of giving $E$. palmifolia extract on the growth of S. paratyphi bacteria but there was no significant difference based on the one way ANOVA test.
\end{abstract}

Keywords: Antimicrobial, Eleutherine palmifolia, Ethanol.

\begin{abstract}
Abstrak
Bawang dayak (Eleutherine palmifolia (L.) Merr.) merupakan salah satu bahan alami yang sering digunakan untuk obat di Kalimantan. E. palmifolia digunakan untuk pengobatan karena mengandung senyawa metabolit sekunder yang berpotensi sebagai antibakteri. Seperti senyawa fenolik, flavonoid, alkaloid, saponin, tannin dan glikosida yang termasuk kedalam senyawa polar. Penelitian bertujuan untuk mengetahui pengaruh ekstrak etanol $70 \%$ E. palmifolia terhadap bakteri Salmonella paratyphi dengan metode ekstraksi teknik maserasi. E. paratyphi merupakan bakteri pathogen terhadap manusia yang habitatnya berada di saluran pencernaan. Penelitian ini dilakukan pengujian aktivitas antibakteri ekstrak E. palmifolia dengan perbandingan konsentrasi ekstrak E. palmifolia $20 \mathrm{mg} / \mathrm{mL}, 30 \mathrm{mg} / \mathrm{mL}, 40 \mathrm{mg} / \mathrm{mL}, 50 \mathrm{mg} / \mathrm{mL}$, dan $60 \mathrm{mg} / \mathrm{mL}$ serta kloramfenikol sebagai kontrol positif dan aquadest steril sebagai kontrol negatif. Metode uji antibakteri yang digunakan yaitu metode difusi dengan cara paper disk sebanyak 5 kali pengulangan. Hasil penelitian menunjukkan adanya pengaruh ekstrak $E$. palmifolia dalam mengambat pertumbuhan bakteri E. paratyphi yang dibuktikan dengan adanya zona hambat yang terbentuk disekitar paper disk pada media dengan konsentrasi $20 \mathrm{mg} / \mathrm{mL}$, $30 \mathrm{mg} / \mathrm{mL}, 40 \mathrm{mg} / \mathrm{mL}, 50 \mathrm{mg} / \mathrm{mL}$, dan $60 \mathrm{mg} / \mathrm{mL}$ dimana rata rata diameter zona hambat berturut-turut $6,6 \mathrm{~mm}, 7,4 \mathrm{~mm}, 8,8 \mathrm{~mm}, 9,9 \mathrm{~mm}$ masuk dalam kategori daya hambat tidak efektif dan $11 \mathrm{~mm}$ masuk dalam kategori lemah. Berdasarkan penelitian yang telah dilakukan, didapatkan hasil adanya pengaruh pemberian ekstrak E. palmifolia terhadap pertumbuhan bakteri S. paratyphi namun tidak ada perbedaan yang signifikan berdasarkan uji one way ANOVA.
\end{abstract}

Kata Kunci: Antimikroba, Eleutherine palmifolia, Etanol. 


\section{PENDAHULUAN}

Pengobatan secara alami dianggap lebih mudah didapatkan karena berada di lingkungan sekitar kita dan harganya relatif murah. Salah satu bahan alami yang sering digunakan untuk obat di Kalimantan adalah bawang dayak (Eleutherine palmifolia (L.) Merr.). Menurut Utami dan Lina (2013) tanaman E. palmifolia mempunyai beberapa khasiat antara lain hipertensi, stroke, diabetes, kanker dan penurunan kadar kolestrol darah.

Selain mempunyai manfaat yang disebutkan di atas, tanaman E. palmifolia juga dapat dimanfaatkan sebagai tanaman herbal yang berpotensi sebagai antimikroba. Senyawa tersebut dihasilkan oleh tanaman berupa metabolit sekunder. Senyawa metabolit sekunder banyak dijumpai pada tanaman herbal yang berpotensi sebagai antibakteri adalah alkaloid, flavonoid, fenol, tanin, saponin, dan steroid-triterpenoid (Donatus, 2016). Tanaman E. palmifolia digunakan untuk pengobatan karena ada kadungan metabolit sekunder. Sebuah penelitian yang telah dilakukan Yuswi (2017) menunjukkan bahwa sebagian senyawa bioaktif yang ada pada tanaman E. palmifolia mempunyai aktivitas senyawa fenolik serta flavonoid. Senyawa tersebut juga aktif sebagai senyawa antibakteri. Penelitian yang dilakukan oleh Nahemia et al., (2019) menujukkan bahwa ekstrak tanaman E. palmifolia dapat menghambat pertumbuhan bakteri S. typhirum pada konsentrasi $40 \mathrm{mg} / 100 \mathrm{~mL}$ sampai dengan $80 \mathrm{mg} / 100 \mathrm{~mL}$ dengan rata rata diameter zona hambat 0,6 $\mathrm{mm}$ sampai 1,0 $\mathrm{mm}$.

Berpedoman pada hasil penelitian yang telah dilakukan oleh Nahemia et al., (2019) perlu dilakukan penelitian lebih lanjut untuk memanfaatkan tanaman herbal yang memiliki manfaat antibakteri seperti tanaman $E$. palmifolia untuk menghambat pertumbuhan bakteri S. typhi (Wulandari, 2019). Banyaknya kasus infeksi demam tifoid karena memiliki kepadatan penduduk 17 juta/ $\mathrm{km}^{2}$ dan mayoritas penduduk bertempat tinggal di daerah urban serta masih kurang sanitasi yang memenuhi standar layak (Rachman, 2017) yang merupakan menjadi penyebab teradinya beberapa kasus infeksi demam tifoid ditemukan di Kalimantan. Demam tifoid yang dialami penderita merupakan demam tifoid dengan patogenitas rendah yang disebabkan oleh genus dari 
bakteri Salmonella yaitu S. paratyphi. Berdasarkan paparan tersebut penulis tertarik untuk meneliti tentang Uji Daya Hambat Ekstrak Bawang Dayak (Eleutherine palmifolia (L.) Merr.) Terhadap Bakteri Salmonella paratyphi.

\section{BAHAN DAN METODE}

Alat yang digunakan dalam penelitian yaitu autoclave, neraca analitik, sendok takar, erlenmeyer, batang pengaduk, cawan petri, ose, pembakar spirtus dan bunsen, korek, gelas ukur / pipet ukur, hot plate, inkubator dan rotary evaporator.

Bahan yang digunakan dalam penelitian ini yaitu aquadest steril, aluminium foil, kapas, paper disk, media Nutrient Broth (NB), media Nutrient Agar (NA), wrapping, ekstrak umbi E. palmifolia, biakan bakteri S. paratyphy, Kloramfenikol, Nacl 0,9\% dan etanol 70\%.

Alat alat gelas dan non gelas yang akan digunakan untuk penelitian terlebih dahulu dilakukan sterilisasi untuk mencegah terjadinya kontaminasi dengan metode sterilisasi kering yaitu oven pada suhu $160^{\circ} \mathrm{C}$ selama 1-2 jam. Sedangkan ose disterilisasi dengan metode sterilisasi kering yaitu dengan menggunakan api langsung (Wulandari, 2019).

Untuk menghasilkan ekstrak yang optimal, maka dalam proses ekstraksi perlu diperhatikan derajat kehalusan (ukuran partikel) simplisia, ukuran partikel simplisia penting untuk mengupayakan agar penarikan senyawa dapat berlangsung semaksimal mungkin karena berhubungan dengan luas permukaan yang akan berkontak dengan pelarut untuk ekstraksi (Sapri et al., 2014). Simplisia adalah bahan alamiah yang dipergunakan sebagai obat yang belum mengalami pengolahan apapun juga dan kecuali dikatakan lain, berupa bahan yang telah dikeringkan. Simplisia dibedakan menjadi simplisia nabati, simplisia hewani dan simplisia pelikan (mineral) (Endarini, 2016 ).

Pembuatan simplisia yang pertama dilakukan yaitu sortasi basah. $E$. palmifolia dibersihkan dari bahan asing lain untuk mengurangi jumLah ikroba awal, lalu dilakukan pencucian menggunakan air bersih karena cara pencucian dapat mempengaruhi jenis dan jumLah mikroba awal pada simplisia kemudian dilanjutkan dengan perajangan. Sebelum dilakukan perajangan sebaiknya 
dijemur di bawah sinar matahari langsung untuk mengurangi pewarnaan akibat reaksi antara bahan dan logam pisau (Prasetyo dan Entang, 2013). Simplisia yang sudah kering tersebut kemudian dihaluskan menggunakan blender. Tujuan penghalusan yaitu untuk memperluas permukaan partikel simplisia pelarut dan mempermudah penetrasi pelarut kedalam simplisia sehingga dapat menarik senyawa-senyawa dari simplisa (Husni et.al., 2018).

\section{Pembuatan Ekstrak}

Umbi E. palmifolia yang telah dikeringkan lalu dihaluskan menjadi serbuk kemudian dimaserasi, yaitu dimasukkan kedalam bejana atau botol gelap dan diberikan label kemudian direndam dengan pelarut alkohol 70\% dengan perbandingan 10 kali berat simplisia tersebut lalu ditutup dengan aluminium foil. Setelah itu dilakukan penyaringan dan didapatkan filtratnya. Filtrat yang didapatkan kemudian diuapkan pelarutnya dengan menggunakan rotary evaporator sehingga diperoleh ekstrak kental E. palmifolia yang bebas pelarut (Wahyuni, 2017).

\section{Pembuatan Media}

Untuk media Nutrien Broth di buat dengan cara ditimbang sebanyak 1,3gram NB, kemudian dilarutkan dengan aquadest sebanyak $100 \mathrm{~mL}$ dan dihomogenkan. Kemudian dididihkan sambil dihomogenkan. Sedangkan media Nutrient Agar dibuat dengan cara ditimbang sebanyak 28 gram NA, kemudian dilarutkan dengan aquadest sebanyak $1000 \mathrm{~mL}$ kemudian dididihkan sambil dihomogenkan. Setelah itu mulut erlemeyer ditutup dengan kapas dan alumunium foil. Larutan media tersebut lalu disterilkan menggunakan autoclave dengan suhu $121^{\circ} \mathrm{C}$ selama 15 menit. Media yang telah disterilkan kemudian didinginkan yang selanjutnya dituangkan pada cawan petri steril \pm 20 $\mathrm{mL}$ di dalam laminator flow dan ditutup dengan wrapping untuk mencegah adanya kontaminasi. Setelah itu didinginkan pada suhu $\pm 45-50^{\circ} \mathrm{C}$ sampai memadat. 


\section{Peremajaan dan Pembuatan Suspensi Bakteri}

Bakteri yang digunakan yaitu bakteri S. paratyphi yang bersifat gram negatif berbentuk batang, bersifat motil dan tidak memproduksi $\mathrm{H}_{2} \mathrm{~S}$ dari keluarga Enterobacteriaceae (Latif et al., 2014 dalam Fauziah, 2018). Bakteri tersebut diambil menggunakan jarum ose steril, lalu diinokulasikan pada media NB kemudian diinkubasi pada suhu $37^{\circ} \mathrm{C}$ selama 24 jam di dalam inkubator. Kemudian dari stok kultur bakteri S. paratyphi yang telah tumbuh diambil menggunakan jarum ose steril lalu disuspensikan dalam tabung reaksi yang berisi $1 \mathrm{~mL} \mathrm{NaCl} \mathrm{0,9 \%} \mathrm{steril.} \mathrm{Campurannya} \mathrm{dibuat} \mathrm{dengan} \mathrm{hingga} \mathrm{kekeruhannya}$ sama dengan suspense standard 0,5 Mc. Farland, yang dianggap mengandung konsentrasi bakteri sebanyak $10^{8} \mathrm{CFU} / \mathrm{mL}$ (Donatus, 2016).

\section{Uji Anti Mikroba}

Menginokulasi bakteri uji S. paratyphi sebanyak $100 \mu$ ke dalam media NA yang telah disiapkan dengan metode pour plate. Kemudian rendam paper disk pada masing-masing konsentrasi yaitu $20 \mathrm{mg} / \mathrm{mL}$ (konsentrasi 1); 30 $\mathrm{mg} / \mathrm{mL}$ (konsentrasi 2); $40 \mathrm{mg} / \mathrm{mL}$ (konsentrasi 3); $50 \mathrm{mg} / \mathrm{mL}$ (Konsetrasi 4); 60 $\mathrm{mg} / \mathrm{mL}$ (Konsentrasi 5); kontrol positif dan kontrol negatif lalu tempelkan pada media yang telah diinokulasi dengan bakteri murni S. paratyphi. Inkubasi dengan suhu $37^{\circ} \mathrm{C}$ selama 24 jam lalu identifikasi zona beningnya yang terbentuk di sekitar paper disk dan diukur menggunakan penggaris. Untuk memperoleh data yang valid berdasarkan rumus Vederer maka dilakukan pengulangan sebanyak lima kali dengan jumLah yang sama pada masing-masing konsentrasi.

Analisis data diolah menggunakan Uji Analysis of Variance (Anova) dengan program SPSS versi 20 untuk menguji satu variabel (konsentrasi ekstrak etanol $70 \%$ tanaman E. palmifolia terhadap pertumbuhan bakteri S. paratyphi, dengan syarat data berdistribusi normal dan homogen.

\section{HASIL}

Berdasarkan penelitian yang sudah dilakukan mengenai uji daya hambat 
umbi E. palmifolia terhadap Bakteri S. paratyphi menggunakan metode difusi dengan paper disk sebanyak 5 kali pengulangan didapatkan hasil terdapat pengaruh pemberian ekstrak E. palmifolia terhadap pertumbuhan bakteri $S$. paratyphi yang di buktikan dengan terbentuknya zona hambat.

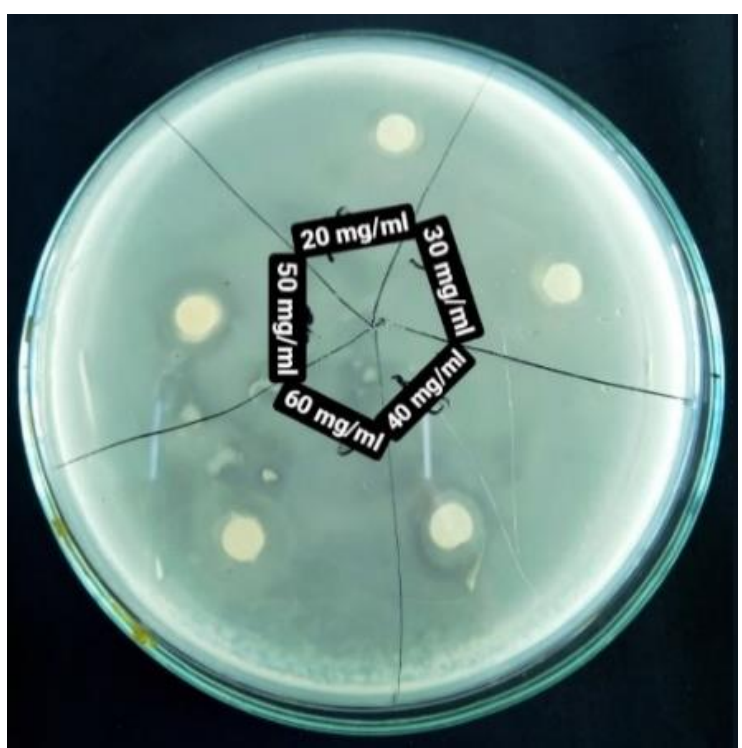

Gambar 1. Zona hambat ekstrak E. palmifolia terhadap bakteri S. paratyphi

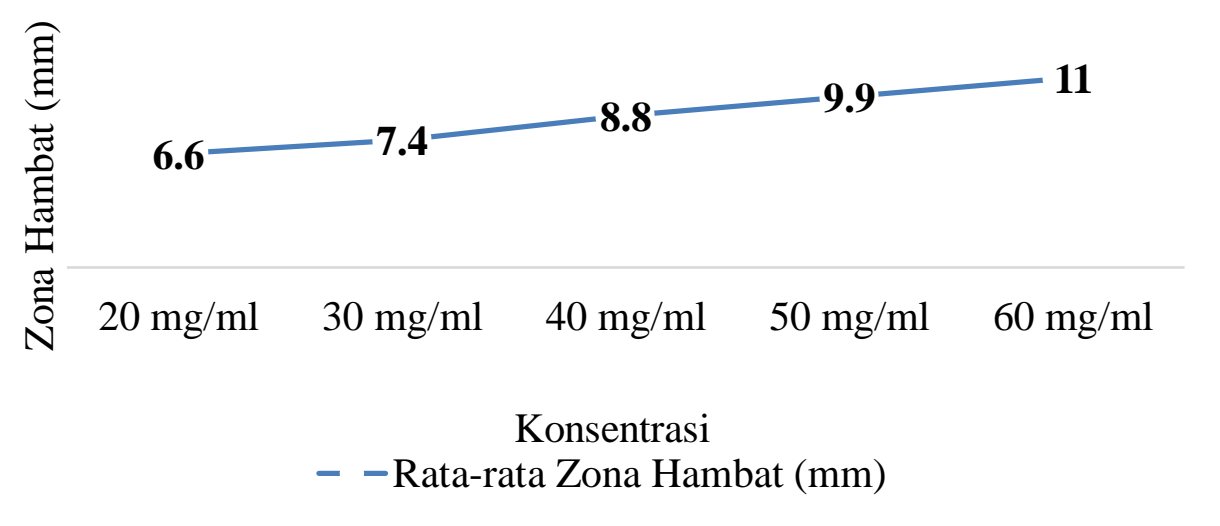

Gambar 2. Rata-rata diameter zona hambat E. palmifolia terhadap bakteri S. paratyphi 
ANOVA

Hasil

\begin{tabular}{|l|r|r|r|r|r|}
\hline & \multicolumn{1}{|c|}{$\begin{array}{c}\text { Sum of } \\
\text { Squares }\end{array}$} & df & Mean Square & F & Sig. \\
\hline Between Groups & 9,360 & 4 & 2,340 &, 573 &, 685 \\
Within Groups & 81,700 & 20 & 4,085 & & \\
Total & 91,060 & 24 & & & \\
\hline
\end{tabular}

Gambar 3. Hasil Uji one way ANOVA

Tukey HSD ${ }^{\text {a }}$

\begin{tabular}{|l|r|r|}
\hline & & \multicolumn{1}{c|}{$\begin{array}{c}\text { Subset for } \\
\text { alpha }=0.05\end{array}$} \\
\cline { 3 - 3 } Konsentrasi & $\mathrm{N}$ & 1 \\
\hline Perlakuan 3 & 5 & 7,8000 \\
Perlakuan 4 & 5 & 8,4000 \\
Perlakuan 5 & 5 & 8,8000 \\
Perlakuan 2 & 5 & 9,1000 \\
perlauan 1 & 5 & 9,6000 \\
Sig. & &, 630 \\
\hline
\end{tabular}

Means for groups in homogeneous subsets are displayed.

a. Uses Harmonic Mean Sample Size $=5,000$.

Gambar 4. Hasil uji post hoc

\section{DISKUSI}

Ekstrak E. palmifolia dapat menghambat pertumbuhan bakteri $S$. paratyphi karena mengandung senyawa bioaktif yang dapat dimanfaatkan sebagai antibakteri. Menurut penelitian yang telah dilakukan Yuswi (2017) menunjukkan bahwa pada tanaman $E$. palmifolia mempunyai aktivitas senyawa fenolik serta flavonoid dimana mekanisme kerja flavonoid sebagai antibakteri yaitu dengan membentuk senyawa kompleks dengan protein ekstraseluler dan terlarut sehingga dapat merusak membran sel bakteri yang diikuti dengan keluarnya senyawa intraseluler (Amalia et al., 2017). Selain itu penelitian Situmeang (2017) juga menunjukkan bahwa ekstrak etanol $E$. palmifolia mengandung senyawa golongan alkaloid, saponin, flavonoid, tannin dan glikosida. Alkaloid bekerja sebagai antibakteri dengan cara mengganggu komponen penyusun peptidoglikan pada sel bakteri sehingga lapisan dinding sel 
tidak terbentuk secara utuh dan menyebabkan kematian sel (Amalia et al., 2017). Senyawa golongan fenolik seperti tannin menghambat pertumbuhan bakteri dengan cara menghambat aktivitas enzim protease pada proses transport protein sel bakteri. Tannin juga dapat mengerutkan dinding sel bakteri sehingga mengganggu permeabillitas membran sel kemudian menyebabkan sel tidak dapat melakukan aktivitas hidup. Hal tersebut dapat menyebabkan pertumbuhan bakteri akan terhambat sehingga sel mati. Mekanisme steroid sebagai antibakteri adalah dengan cara merusak membran sel. Sedangkan senyawa kimia glikosida berpotensi sebagai antibakteri dengan cara berpenetrasi kedalam dinding sel sehingga menyebabkan rusaknya dinding sel bakteri (Jannah et al., 2017). Mekanisme antibakteri yang dimiliki senyawa saponin dengan mengganggu stabilitas membran sel bakteri sehingga mnyebabkan bakteri lisis (Zahro dan Agustini, 2013). E. palmifolia memiliki potensi sebagai obat herbal dimana telah terbukti dapat menghambat pertumbuhan beberapa jenis bakteri dan jamur seperti Staphylococcus epidermidis, Eschercia coli, dan Candida albicans (Yuniasih, 2018).

Hasil penelitian ini tidak jauh berbeda dengan penelitian yang dilakukan oleh Nafii'ah (2015) yang menyatakan bahwa ekstrak etanol E. palmifolia dapat menghambat pertumbuhan bakteri Salmonella typhi yang hasilnya menujukkan bahwa pada konsentrasi $20 \mathrm{mg} / \mathrm{mL}$ dan $40 \mathrm{mg} / \mathrm{mL}$ dapat menghambat pertumbuhan bakteri S. typhi dimana pada konsentrasi $40 \mathrm{mg} / \mathrm{mL}$ tersebut mempunyai daya hambat yang terbaik. Pada penelitian lain yang dilakukan oleh Putri et al., (2020) tentang uji efektivitas ekstrak etanol E. palmifolia didapatkan hasil bahwa ekstrak E. palmifolia tersebut dapat menghambat beberapa bakteri seperti terhadap bakteri Staphylococcus aureus, Escherchia coli dan Salmonella paratyphi. Hasil tersebut sama halnya dengan penelitian yang telah dilakukan Hal ini menunjukkan bahwa $E$. palmifolia memiliki daya hambat bakteri yang tinggi.

Penelitian ini menunjukkan bahwa pemberian ekstrak $E$. palmifolia dapat menghambat pertumbuhan bakteri S. paratyhi akan tetapi tidak dapat membunuh karena setelah masa inkubasi zona hambat yang telah terbentuk tertutup kembali oleh bakteri. Terdapat beberapa faktor yang dapat 
mempengaruhi rendahnya zona hambat yang terbentuk yang menjadi keterbatasan dalam penelitian ini seperti saat pemanasan pada proses pengeringan dan pemekatan ekstrak menggunakan rotary evaporator sehingga mempengaruhi penurunan kandungan flavonoid. Proses pemanasan dapat mengakibatkan penurunan kadar total flavonoid sebesar 15-78\% (Saa'dah et al., 2017). Berdasarkan penelitian yang telah dilakukan oleh Sekarsari et al., (2019) suhu $45^{\circ}$ memberikan perlakukan terbaik berdasarkan nilai aktifitas senyawa bioaktif yang tinggi dari total flavanoid, total fenol dan total tannin.

Uji daya hambat ekstrak E. palmifolia terhadap bakteri S. typhi ini dilakukan dengan metode difusi menggunakan paper disk. Menurut Nahemia (2019) prinsip metode pada paper disk yaitu senyawa bioaktif yang terkandung dalam umbi E. palmifolia yang telah terserap pada paper disk akan berdifusi kedalam media yang telah diinokulasian mikroba uji. Senyawa bioaktif yang terserap tersebut akan menghambat pertumbuhan mikroba atau membunuh mikroba yang ditujukkan dengan terbentuknya diameter zona hambat di sekitar paper disk setelah diinkubasi.

Kontrol positif yang digunakan yaitu kloramfenikol karena kloramfenikol merupakan antimikroba dengan spektrum kerja luas dan umumnya bersifat bakteriostatis terhadap Enterobacter dimana mekanisme kerjanya dengan cara menghambat sistesis protein kuman (Indijah dan Purnama, 2016). Sedangkan kontrol negatif yang digunakan yaitu aquadest steril yang menujukkan hasil tidak adaya respon dalam menghambat bakteri S. typhi karena aquadest steril tidak berefek terhadap pertumbuhan bakteri. Selain itu aquadest digunakan segabai pelarut ekstrak, sehingga yang dapat menghambat bakteri S. paratyphi murni dari ekstraknya tidak ada pengaruh dari pelarutnya.

Pada gambar 1. dapat dilihat bahwa diameter zona hambat yang dihasilkan dari berbagai konsentrasi memiliki diameter yang berbeda-beda sehingga memiliki kriteria respon daya hambat yang berbeda-beda pula. Berdasarkan klasifikasi respon hambat pertumbuhan bakteri, pada konsentrasi $20 \mathrm{mg} / \mathrm{mL}$ yang menunjukkan daya hambat sebesar 6,6 $\mathrm{mm}$ termasuk dalam kategori tidak efektif karena diameter zona beningnya kurang dari $10 \mathrm{~mm}$. Pada konsentrasi $30 \mathrm{mg} / \mathrm{mL}, 40 \mathrm{mg} / \mathrm{mL}, 50 \mathrm{mg} / \mathrm{mL}$ yang masing masing berurutan 
menunjukkam zona hambat yang terbentuk sebesar 7,4 mm, 8,8 mm, 9,9 mm juga tergolong ke dalam kategori tidak efektif dalam menghambat pertumbuhan bakteri S. paratyphi. Sedangkan pada konsentrasi $60 \mathrm{mg} / \mathrm{mL}$ menghasilkan zona bening yang paling tinggi ditunjukkan dengan zona bening yang terbentuk sebesar $11 \mathrm{~mm}$ yang jika digolongkan ke dalam klasifikasi mempunyai kategori daya hambat yang sedang. Hal ini menujukkan bahwa ekstrak etanol umbi $E$. palmifolia memiliki senyawa yang mengandung antibakteri yang dapat menghambat pertumbuhan bakteri S. paratyphi walaupun termasuk dalam kriteria kurang efektif dan sedang.

Selanjutnya dilakukan analisa data menggunakan uji One Way ANOVA dengan syarat yaitu uji normalitas dan uji homogenitas variasi. Hasil dari uji normalitas dan homogenitas menunjukkan nilai > 0,05 yang berarti data berdistribusi normal. Kemudian dilajutkan uji One Way ANOVA yang menunjukkan nilai signifikasi $0,685>0,05$ yang berarti $\mathrm{H}_{0}$ ditolak atau tidak terdapat perbedaan perlakuan diantara variasi uji atau perbedaan yang signifikan karena konsentrasi yang dipakai terlalu kecil sehingga hasil interval konsentrasinya terlalu dekat dan tidak ada perbedaan yang bermakna. Karena $\mathrm{H}_{0}$ ditolak maka dilakukan uji lanjutan yaitu uji post hoc dimana nilai signifikasi yang dihasilkan menunujukkan > 0,05 yang artinya perbedaan antar daya hambat yang terbentuk tidaklah signifikan.

\section{KESIMPULAN}

Berdasarkan penelitian yang sudah dilakukan mengenai uji daya hambat umbi E. palmifolia terhadap bakteri S. paratyphi menggunakan metode difusi cakramsebanyak 5 kali pengulangan didapatkan hasil yang ditandai dengan terbentuknya rata-rata zona hambat pada masing-masing konsentrasi 20 $\mathrm{mg} / \mathrm{mL}, 30 \mathrm{mg} / \mathrm{mL}, 40 \mathrm{mg} / \mathrm{mL}, 50 \mathrm{mg} / \mathrm{mL}$ dan $60 \mathrm{mg} / \mathrm{mL}$ sebesar $6,6 \mathrm{~mm}, 7,4$ $\mathrm{mm}, 8,8 \mathrm{~mm}, 9,9 \mathrm{~mm}$ dan $11 \mathrm{~mm}$. Kemudian dilajutkan uji One Way ANOVA yang menunjukkan nilai signifikasi 0,685 > 0,05 yang berarti $\mathrm{H}_{0}$ ditolak. Karena $\mathrm{H}_{0}$ ditolak maka dilakukan uji lanjutan yaitu uji post hoc dimana nilai signifikasi yang dihasilkan menunujukkan > 0,05 yang artinya perbedaan antar daya 
hambat yang terbentuk tidaklah signifikan.

\section{UCAPAN TERIMAKASIH}

Terimakasih kepada Prodi DIII Analis Kesehatan STIKes Borneo Cendekia Medika Pangkalan Bun.

\section{KONFLIK KEPENTINGAN}

Tidak ada konflik kepentingan dalam penyusunan jurnal ini.

\section{REFRENSI}

Amalia, A., Sari, I. dan Nursanty, R. (2017). Aktivitas Antibakteri Ekstrak Etil Asetat Daun Sembung (Blumea balsamifera (L.) DC.) Terhadap Pertumbuhan Bakteri Methicilin Resistant Staphylococcus aureus (MRSA). Prosiding Seminar Nasional Biotik. ISBN: 978-602-60401-3-8.

Donatus, A. (2016). Efek Antibakteri Kombinasi Infusa Umbi Bawang Dayak (Eleutherine americana (Aubl.) Merr. Ex K. Heyne dan Infusa Daun Mangga Bacang (Mangifera foetida L.) Terhadap Salmonella typhi Secara In Vitro. Skripsi. Universitas Tanjungpura. Pontianak. Husni, E., N. Suharti dan A. P. T. Atma. (2018). Karakterisasi Simplisia dan Ekstrak Daun Pacar Kuku (Lawsonia inermis Linn) Serta Penentuan Kadar Fenolat Total dan Uji aktivitas Antioksidan. Jurnal Sains Farmasi \& Klinis. 5 (1): 12-16.

Indijah, S. W. dan P. Fajri. (2016). Farmakologi. Jakarta Selatan : Pusdik SDM Kesehatan Badan Pengembangan dan Pemberdayaan Sumber Daya Manusia Kesehatan.

Leba, M. A. U. (2017). Buku Ajar Ekstraksi dan Real Kromatografi. Yogyakarta: Penerbit Depublish.

Jannah, R, Muhammad A. H. dan Risa N. (2017). Inhibition Test of Methanol Extract From Soursop Leaf (Annona muricata Linn.) Against Streptococcus mutans Bacteria. Jurnal Natural. 17 (1): 23-30. DOI: https//doi.org/10.24815/jn. v17 i.6823.

Naafi'ah, F. A., (2015). Efektivitas Ekstrak Bawang Dayak (Eleutherine palmifolia (L.) Merr.) dalam Menghambat Pertumbuhan Bakteri Salmonella typhi. Skripsi. Universitas Islam Negeri Syarif Hidayatullah. Jakarta.

Nahemia Y., Ismanto, A. dan Ardhani, F. (2019). Uji Efektifitas Ekstrak Bawang Dayak (Eleutherine americana Merr.), Mangrove Avicennia marina, dan Mangrove Sonneratia alba Terhadap Salmonella typhimurium Secara In Vitro. Jurnal Peternakan Lingkungan Tropis. 2 (2) : 12-17. ISSN: 26542501.Prasetyo dan E. Inoriah. (2013). Pengelolaan Budidaya Tanaman 
Obat-obatan (Bahan Simplisia). Badan Penerbitan Fakultas Pertanian UNIB. Bengkulu.

Putri, R. A., Simbala, H. E. I. dan Mpila, D. A. (2020). Uji Aktivitas Antibakteri Ekstrak Etanol bawang Dayak (Eletherine americana Merr) Terhadap Bakteri Staphylococcus aureus, Escherchia coli dan Salmonellat typhi. Pharmacon. 9 (4): 525-532. DOI: https//doi.org/10.35799/pha.9.2020.31360.

Rachman, Y. N. (2017). Karakteristik Penderita Demam Tifoid Rawat Inap Anak di RSUD Abdul Wahab Sjahrane Samarinda. Publikasi Ilmiah. Universitas Muhammadiyah Surakarta.

Sa'adah, H., Nurhasnawati, H. dan Permatasari, V. (2017). Pengaruh Metode Ekstraksi Terhadap Kadar Flavanoid Umbi Bawang Dayak (Eleutherine palmifolia (L.) Merr.) Dengan Metode Spektrofotometri. Jurnal Borneo Journal of Pharmascientech. 1 (1) : 1-9. ISSN: 2548-3897

Situmeang, S. J. (2017). Karakterisasi dan Skrining Fitokimia Serta Uji Antioksidan Ekstrak Etanol Umbi Bawang Dayak (Eleutherine palmifolia (L.) Merr.). Skripsi. Universitas Sumatera Utara. Medan.

Suhendra, C. P., Widarta, I. R. dan Wiadnyani, A. A. I. S. (2019). Pengaruh Konsentrasi Etanol Terhadap Aktivitas Antioksidan Ekstrak Rimpang Ilalang (Imperata cylindrica (L.) Beauv.) Pada Ekstraksi Menggunakan Gelombang Ultrasonik. Jurnal Ilmu dan Teknologi Pangan. 8 (1): 27 - 35. ISSN: 25278010.

Utami, P. dan L. Mardiana. (2013). Umbi Ajaib Tumpas Penyakit. Jakarta: Penebar Swadaya.

Wahyuni. (2017). Pengaruh Konsentrasi Ekstrak Alga Hijau (Caulerpa racemose) dengan Ekstrak Umbi Bawang Dayak (Eleutherine americana (Aubl) Merr) terhadap kemampuan Sekresi Nitrit Oksida Pada Makrofag Tikus (Ratus norvegicus) Secara In Vitro. Skripsi. Universitas Hasanuddin. Makasar.

Wulandari, I. T. (2019). Uji Aktivitas Antibakteri Fraksi N-Heksana Umbi Eleutherine palmifolia (L.) Pada Bakteri Salmonella typhi Dengan Metode Difusi cakram. Skripsi. Universitas Muhamadiyah Malang.

Yunasih, M.M. (2018). Pengaruh Daya Hambat Antimikroba Isolat Alkaloid Umbi Bawang Dayak (Eleutherine palmifolia) terhadap Pertumbuhan Escherchia coli, Staphylococcus epidemidis, dan Candida albicans ATCC 10231 Secara In-Vitro. Skripsi. Universitas Sanata Dharma. Yogyakarta.

Yuswi, N. C. R. (2017). Ekstraksi Antioksidan Bawang Dayak (Eleutherine palmifolia) Dengan Metode Ultrasonic Bath (Kajian Jenis Pelarut dan Lama Ekstraksi). Jurnal Pangan dan Agroindustri. 5 (1): 71-79.

Zahro, L. dan Agustini, R. (2013). Uji Efektivitas Antibakteri Ekstrak Kasar Saponin Jamur Tiram Putih (Pleurotus ostreatus) Terhdap Staphylococcus aureus dan Escherchia coli. Unesa Journal of Chemistry. 2 (3): 120-129. 